\title{
4-Methylcoumarin Derivatives with Anti-inflammatory Effects in Activated Microglial Cells
}

\author{
Anna Rita Togna, ${ }^{a}$ Omidreza Firuzi, ${ }^{b}$ Valentina Latina,,${ }^{a, \dagger}$ Virinder Singh Parmar, ${ }^{c}$ \\ Ashok Kumar Prasad, ${ }^{c}$ Adele Salemme, ${ }^{a}$ Giuseppina Ines Togna, ${ }^{*, a}$ and Luciano Saso ${ }^{a}$ \\ ${ }^{a}$ Department of Physiology and Pharmacology "Vittorio Erspamer," Sapienza University of Rome; Rome 00185, \\ Italy: ${ }^{b}$ Medicinal and Natural Products Chemistry Research Center, Shiraz University of Medical Sciences; Shiraz \\ 71348-53734, Iran: and ${ }^{c}$ Department of Chemistry, University of Delhi; Delhi 110007, India. \\ Received July 20, 2013; accepted October 13, 2013
}

\begin{abstract}
Inflammation contributes to the pathogenesis of neurodegenerative diseases and anti-inflammatory compounds may have a role in prevention or treatment of these pathologies. 4-Methylcoumarins are effective antioxidants with anti-inflammatory properties. In this study, the inhibitory effects of two 4-methylcoumarin derivatives, 7,8-dihydroxy-3-ethoxycarbonylmethyl-4-methylcoumarin (DHEMC) and 7,8-diacetoxy-3-ethoxycarbonylmethyl-4-methylcoumarin (DAEMC) were examined on the inflammatory processes induced by lipopolysaccharide (LPS) in activated primary rat microglial cultures. LPS-induced production of nitric oxide (NO, measured by Griess method) and other pro-inflammatory mediators, thromboxane (TX) $\mathrm{B}_{2}$ and prostaglandin (PG) $E_{2}$ (both determined by radioimmunoassay (RIA)), as well as tumor necrosis factor (TNF)- $\alpha$ (determined by enzyme-linked immunosorbent assay (ELISA)) were inhibited in the presence of

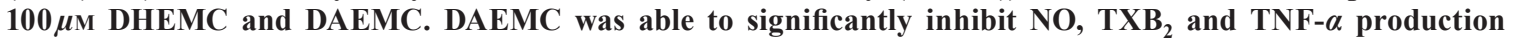
also at $50 \mu \mathrm{M}$. Both compounds at $100 \mu \mathrm{M}$ significantly lowered cyclooxygenase-2 (COX-2) protein expression in LPS-stimulated microglial cells measured by Western blot, but only DAEMC showed an inhibitory effect on inducible nitric oxide synthase (iNOS) protein expression at $100 \mu \mathrm{M}$. In conclusion, our findings show that 4-methylcoumarin derivatives can modulate inflammatory pathways in microglial cells, probably by acting at the protein expression level.
\end{abstract}

Key words 4-methylcoumarin; inflammation; microglia; inducible nitric oxide synthase (iNOS); cyclooxygenase-2 (COX-2)

Genetic studies have shown that genes involved in inflammation are associated with an increased risk of Alzheimer's disease. ${ }^{1)}$ Further, epidemiological reports have demonstrated that the use of nonsteroidal anti-inflammatory drugs (NSAIDs) can lower the risk of development of Alzheimer's disease. ${ }^{2)}$ Although, it is not very clear whether inflammation is the cause or the consequence of neurodegeneration, persistent inflammation can be harmful to the central nervous system (CNS), ${ }^{3)}$ especially in the early stages of development of Alzheimer's disease. ${ }^{4)}$ Therefore, anti-inflammatory compounds that can modulate neuroinflammation could prove useful for prevention of neurodegenerative diseases. ${ }^{4)}$

Coumarins are a large class of naturally occurring compounds with several biological activities such as antitumoral ${ }^{5)}$ and antioxidant activities. ${ }^{6}$ Recently, much attention has been focused on the anti-inflammatory activity of coumarin derivatives. $^{7-10)}$

4-Methylcoumarins, a subclass of coumarin compounds, are effective antioxidant ${ }^{11-14)}$ and anti-inflammatory agents. ${ }^{9,11,15,16)}$ 4-Methylcoumarins bearing 7,8-ortho-dihydroxy or 7,8-orthodiacetoxy moieties have been found to be better radical scavengers and antioxidants. ${ }^{12,17)}$

On the other hand, the insertion of ethoxycarbonylmethyl moiety at $\mathrm{C} 3$ position does not lower the activity of these compounds and may increase the lipophilicity. ${ }^{14)}$ Increased lipophilicity is a very important physicochemical property that enables the compound to cross the cell membranes and reach

The authors declare no conflict of interest.

${ }^{\dagger}$ Present address: European Brain Research Institute (EBRI); Rome 00143, Italy. its intracellular targets.

In this study, the effects of two 4-methylcoumarin derivatives, 7,8-dihydroxy-3-ethoxycarbonylmethyl-4-methylcoumarin (DHEMC) and 7,8-diacetoxy-3-ethoxycarbonylmethyl4-methylcoumarin (DAEMC), on the lipopolysaccharide (LPS)-induced production of pro-inflammatory mediators as well as protein expression levels of pro-inflammatory enzymes were studied in microglial cells.

\section{MATERIALS AND METHODS}

Chemicals DHEMC and DAEMC were synthesized and characterized as described earlier. ${ }^{18)}$ DHEMC was obtained from 7,8-dihydroxy-4-methylcoumarin (synthesized by using Pechmann condensation of pyrogallol with ethyl acetoacetate) by introduction of an ethoxycarbonylmethyl group at the $\mathrm{C} 3$ position; DAEMC was obtained by acetylation of DHEMC

Table 1. Structures of Tested 4-Methylcoumarin Derivatives

\begin{tabular}{lllllll} 
\\
\hline $\mathrm{DHEMC}^{a}$ & $-\mathrm{CH}_{2} \mathrm{COOCH}_{2} \mathrm{CH}_{3}$ & $-\mathrm{H}$ & $-\mathrm{H}$ & $-\mathrm{OH}$ & $-\mathrm{OH}_{2}$ \\
$\mathrm{DAEMC}^{b)}$ & $-\mathrm{CH}_{2} \mathrm{COOCH}_{2} \mathrm{CH}_{3}$ & $-\mathrm{H}$ & $-\mathrm{H}$ & $-\mathrm{OOCH}_{3}$ & $-\mathrm{OOCH}_{3}$ \\
\hline
\end{tabular}

a) 7,8-Dihydroxy-3-ethoxycarbonylmethyl-4-methylcoumarin. b) 7,8-Diacetoxy-3-ethoxycarbonylmethyl-4-methylcoumarin. 
(Table 1). Dulbecco's modified Eagle's medium (DMEM) and fetal calf serum (FCS) were obtained from Invitrogen. LPS, 3-(4,5-dimethylthiazol-2-yl)-2,5-diphenyltetrazolium bromide (MTT), N-(1-napthyl)-ethylenediamine dihydrocloride, penicillin/streptomycin, $o$-phosphoric acid $\left(\mathrm{H}_{3} \mathrm{PO}_{4}\right)$, sodium nitrite and sulfamilamide were purchased from Sigma-Aldrich. Tumor necrosis factor (TNF)- $\alpha$ kit was from IBL (Hamburg, Germany). Polyclonal anti-inducible nitric oxide synthase (iNOS) and anti-cyclooxygenase-2 (COX-2) antibodies were from Cayman Chemicals (Ann Arbor, MI, U.S.A.). Western blot enhanced chemiluminescence detection system was from Bio-Rad Laboratory (Hercules, CA, U.S.A.)

Primary Rat Microglial Cell Cultures All the animalrelated procedures were conducted in accordance with European Communities Council Directive n ${ }^{\circ}$ 86/609/EEC. Primary rat microglial cells were obtained, as previously described by Giulian and Baker ${ }^{19)}$ with some modifications. The glial cells, derived from 1- or 2-d-old Wistar rats, were cultured for $11-14 \mathrm{~d}$ in Dulbecco's MEM containing 10\% inactivated fetal bovine serum and antibiotics $(100 \mathrm{U} / \mathrm{mL}$ of penicillin and $100 \mu \mathrm{g} / \mathrm{mL}$ of streptomycin). Afterwards, microglial cells were detached from the astrocyte monolayer by gentle shaking and re-suspended in D-MEM/F12 supplemented with 10\% fetal calf serum and antibiotics as above. Then, the cells were plated into 24 -well plates at a density of $5 \times 10^{5}$ cells/well. Purity of microglial cell populations $(>98 \%)$ was verified by staining with IBA-1 $(1: 1000)$ antibody. After $2 \mathrm{~h}$ the medium was replaced with fresh medium. Compounds DHEMC and DAEMC dissolved in dimethylsulfoxide (DMSO), were added at different concentrations $(10,50$ and $100 \mu \mathrm{M})$ to microglial cultures $30 \mathrm{~min}$ before stimulation by LPS $10 \mathrm{ng} / \mathrm{mL}$ (from Escherichia coli serotype 026:B6). The control group was treated with DMSO diluted in the culture medium at the same final concentration used for 4-methylcoumarin compounds $(0.5 \%)$. The supernatants were collected after $24 \mathrm{~h}$ incubation and kept at $-80^{\circ} \mathrm{C}$ for measurements of nitric oxide (NO), prostanoids [thromboxane $\mathrm{B}_{2}\left(\mathrm{TXB}_{2}\right)$ and prostaglandin $\mathrm{E}_{2}\left(\mathrm{PGE}_{2}\right)$ ], and TNF- $\alpha$ production. Cells were used for subsequent protein measurement, MTT assay and western blot analysis. These experimental conditions were kept constant in all performed tests in this study.

Cell Viability Cell viability was assessed by MTT assay. In this assay, mitochondrial dehydrogenase enzyme of living cells converts yellow MTT to purple formazan, which is spectrophotometrically measured. In brief, microglial cells at a density of $5 \times 10^{4}$ cells/well were seeded in into 96 -well plates and treated with DHEMC and DAEMC at 50 and $100 \mu \mathrm{M}$ for $24 \mathrm{~h}$. Then, the medium was removed and the cells were incubated with MTT $(0.5 \mathrm{mg} / \mathrm{mL})$ for $4 \mathrm{~h}$ at $37^{\circ} \mathrm{C}$. Formazan crystals in the cells were solubilized with DMSO. The level of formazan in each well was determined by measuring its absorbance at $570 \mathrm{~nm}$.

NO Production in Microglial Cells NO production in microglial culture supernatants was evaluated by measuring nitrite, a stable end product of NO. Nitrite was determined by a colorimetric assay with Griess reagent. One-hundred microliter of culture medium reacted with an equal volume of Griess reagent (one part of 1\% sulfanilamide dissolved in $5 \% \mathrm{H}_{3} \mathrm{PO}_{4}$ and one part of $0.1 \%$ naphthylethylenediamine dissolved in distilled water) in 96-well culture plates for $10 \mathrm{~min}$ at room temperature. The absorbance was measured with a microplate reader at $545 \mathrm{~nm}$ using a calibration curve of sodium nitrite standards $(0.7-50 \mu \mathrm{M})$.

Prostanoid and TNF- $\alpha$ Production in Microglial Cells $\mathrm{PGE}_{2}$ and $\mathrm{TXB}_{2}$ (the stable breakdown product of $\mathrm{TXA}_{2}$ ) concentrations were measured in supernatants by radioimmunoassay (RIA). ${ }^{20)}$ The least detectable concentration was $2 \mathrm{pg}$ / $\mathrm{mL}$ for both assays. TNF- $\alpha$ was measured in supernatants by a commercially available kit.

Western Blot Analysis Microglial cells were lysed in $100 \mu \mathrm{L}$ of lysis buffer $(50 \mathrm{~mm}$ Tris- $\mathrm{HCl}, \mathrm{pH} 7.5,0.15 \mathrm{M}$ $\mathrm{NaCl}, 1 \%$ Triton $\mathrm{X}-100,1 \mathrm{~mm}$ ethylenediaminetetraacetic acid (EDTA), 10\% glycerol) containing a protease inhibitor cocktail at $4^{\circ} \mathrm{C}$. After $1 \mathrm{~h}$, lysates were collected, cellular debris were pelleted by centrifugation $\left(1000 \times \mathbf{g}, 10 \mathrm{~min}, 4^{\circ} \mathrm{C}\right)$ and supernatants were collected and stored at $-80^{\circ} \mathrm{C}$ until use for immunobloting. Protein concentration of each lysate was determined by Bradford assay. Equal amounts of total protein $(30 \mu \mathrm{g})$ were electrophoretically separated by a $10 \%$ sodium dodecyl sulfate-polyacrylamide gel electrophoresis (SDS-PAGE) gel and transferred to nitrocellulose membrane. The membranes were blocked with 5\% non-fat milk in Trisbuffered saline-Tween 20 (TBST) for $1 \mathrm{~h}$ and then washed three times with TBST. Primary antibodies for iNOS and COX-2 were added at proper dilutions (1:1000 for polyclonal anti-iNOS, and 1:100 for polyclonal anti-COX-2) in TBST containing $5 \%$ non-fat milk and incubated overnight at $4{ }^{\circ} \mathrm{C}$. After several washes, the membranes were incubated with a horseradish peroxidase (HRP)-conjugated anti-rabbit secondary antibody $(1: 5000)$ for $1 \mathrm{~h}$ at room temperature and immunoreactivity was visualized using chemiluminescence (ECL) reagent (Bio-Rad) according to manufacturer's instructions. Scanning densitometry was performed using the ImageJ 1.47 program, and signal density was normalized to $\beta$-actin density.

In Vitro Cyclooxygenase Inhibition COX-1 activity was measured by determination of $\mathrm{TXB}_{2}$ production by platelets, after spontaneous clotting of human whole blood. ${ }^{21,22)} \mathrm{COX}-2$ activity was determined by assessment of LPS-induced $\mathrm{PGE}_{2}$ production by monocytes in human whole blood. ${ }^{21,22)}$

Briefly, fresh human venous blood from healthy donors was collected in glass tubes without anticoagulant (COX-1 assay) or containing heparin $15 \mathrm{IU} / \mathrm{mL}$ (COX-2 assay) (1 volunteer for each experiment). The volunteers had not taken any NSAIDs during the last 2 weeks before sampling. Aliquots of blood $(0.5 \mathrm{~mL})$ were immediately transferred to tubes containing $2 \mu \mathrm{L}$ of test compound dissolved in DMSO or DMSO alone (control samples).

For COX-1 assay, samples were vortex-mixed and incubated at $37^{\circ} \mathrm{C}$ for $1 \mathrm{~h}$. The tubes were then centrifuged at $5000 \times \boldsymbol{g}$ for $10 \mathrm{~min}$ and $120 \mu \mathrm{L}$ of serum was taken and mixed with $480 \mu \mathrm{L}$ of methanol to precipitate the proteins. Samples were centrifuged again and the supernatants were used for measurement of $\mathrm{TXB}_{2}$ by RIA. ${ }^{20)}$ Each compound was tested 3-4 times in independent experiments performed on the blood obtained from different volunteers.

For COX-2 assay, samples were vortex-mixed and incubated at $37^{\circ} \mathrm{C}$ for $15 \mathrm{~min}$. Then, LPS was added to each tube except for negative control vials. Samples were incubated overnight and plasma was separated by centrifugation and proteins were precipitated as described above. $\mathrm{PGE}_{2}$ was measured in samples by RIA. ${ }^{20)}$ 
Statistical Analysis Data are presented as means \pm standard deviation (S.D.). The statistical significance of differences among groups was performed with one-way ANOVA, followed by post hoc Dunnett's test. The level of significance was set at $p<0.05$.

\section{RESULTS}

Effect on Cell Viability Treatment of microglia with DHEM or DAEMC (50 and $100 \mu \mathrm{M}$ ) for $24 \mathrm{~h}$ did not cause any change of absorbance in MTT assay, indicating that these compounds did not affect the viability of microglial cells (Fig. 1).

Inhibition of NO Production in Microglial Cells NO production by microglia was increased after treatment with LPS (Fig. 2). DHEMC significantly inhibited LPS induced NO production by microglial cells at the concentration of $100 \mu \mathrm{M}$, while DAEMC elicited a significant inhibitory effect at the concentration of 50 and $100 \mu \mathrm{M}$. No inhibitory effect was re-

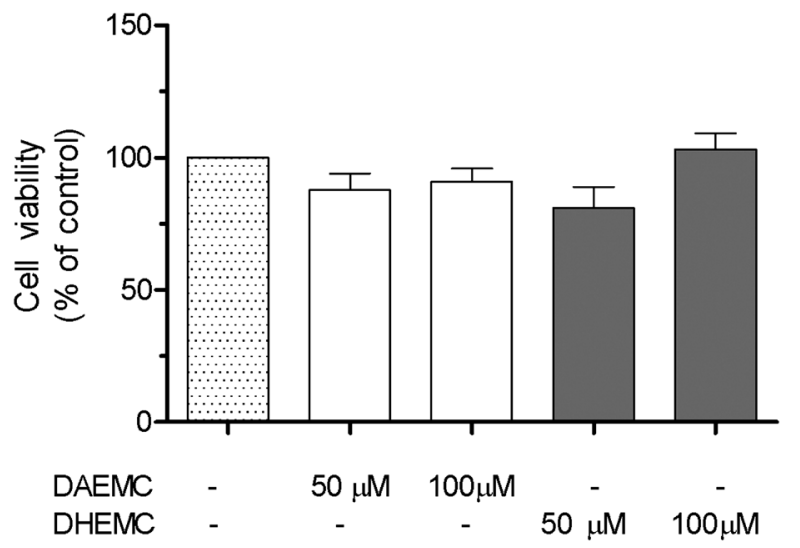

Fig. 1. Effect of 4-Methylcoumarin Derivatives on Microglial Cell Viability

Primary rat microglial cells were treated with DHEMC and DAEMC for $24 \mathrm{~h}$ The cell viability was assessed by MTT reduction assay. Values are expressed as mean \pm S.D. of 4 different experiment.

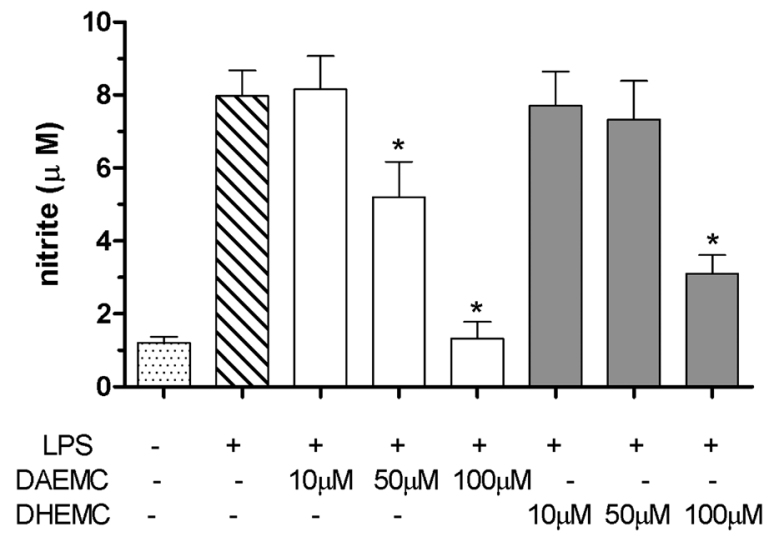

Fig. 2. Inhibitory Effect of 4-Methylcoumarin Derivatives on Rat Microglial Lipopolysaccharide (LPS)-Induced Production of Nitric Oxide (NO)

NO production was evaluated in microglial culture supernatants by measuring nitrite, a stable end product of NO. Primary rat microglial cultures were preincubated with DHEMC and DAEMC for $30 \mathrm{~min}$ and then stimulated with $10 \mathrm{ng}$ / $\mathrm{mL}$ LPS. NO was measured in the culture medium by the Griess method after $24 \mathrm{~h}$. The bars and error bars represent the mean and S.D., respectively. Significantly different from the value in LPS alone treated control cells: ${ }^{*} p<0.05(n=4)$. corded at $10 \mu \mathrm{M}$ for any of the two compounds.

In the experiments performed on microglia in the absence of LPS stimulation, none of the test compounds altered NO production by microglial cells (data not shown).

Inhibition of Prostanoid Production in Microglial Cells Effect of 4-methylcoumarin derivatives was also investigated on LPS-induced production of inflammatory prostanoids, $\mathrm{TXB}_{2}$ and $\mathrm{PGE}_{2}$ (Fig. 3). Compound DHEMC was capable of inhibiting the production of both prostanoids at $100 \mu \mathrm{M}$, however no effect was observed at lower concentrations of 10 and $50 \mu \mathrm{M}$. Pretreatment of microglial cells with DAEMC significantly inhibited LPS-induced production of $\mathrm{TXB}_{2}$ at 50 and $100 \mu \mathrm{M}$ (Fig. 3A), but its inhibitory effect on $\mathrm{PGE}_{2}$ reached significance only at $100 \mu \mathrm{M}$ (Fig. 3B).

In the experiments performed on microglia in the absence of LPS stimulation, none of the test compounds altered prostanoids production by microglial cells (data not shown).

\section{A}

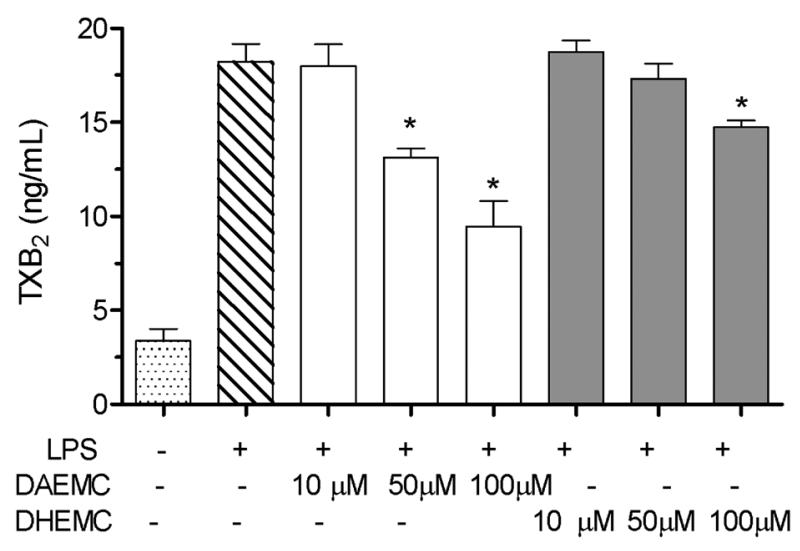

B
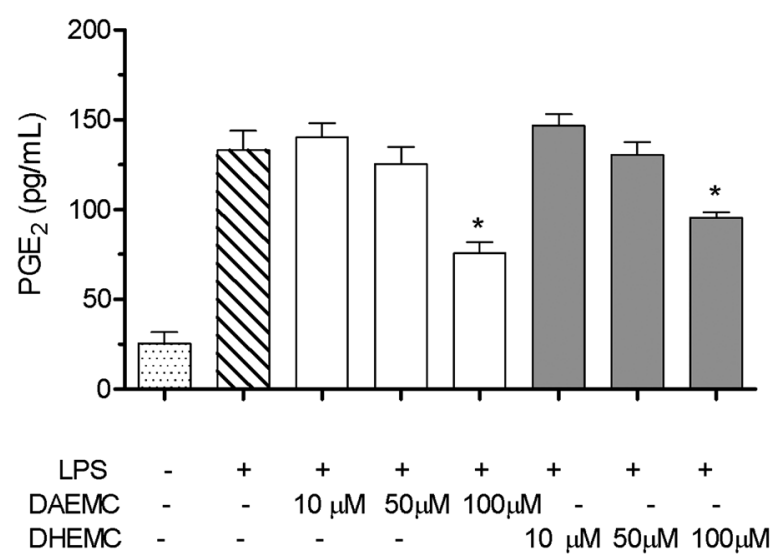

Fig. 3. Inhibitory Effect of 4-Methylcoumarin Derivatives on Rat Microglial Lipopolysaccharide (LPS)-Induced Production of Thromboxane $\mathrm{A}_{2}\left(\mathrm{TXA}_{2}\right)$ and Prostaglandin $\mathrm{E}_{2}\left(\mathrm{PGE}_{2}\right)$

Primary rat microglial cultures were pre-incubated with DHEMC and DAEMC for $30 \mathrm{~min}$ and then stimulated with $10 \mathrm{ng} / \mathrm{mL}$ LPS. $\mathrm{TXB}_{2}$, the stable breakdown product of $\mathrm{TXA}_{2}$, (A) and $\mathrm{PGE}_{2}$ (B) were measured in the culture medium after $24 \mathrm{~h}$. The bars and error bars represent the mean and S.D., respectively. Significantly different from the value in LPS alone treated control cells: ${ }^{*} p<0.05(n=4)$. 


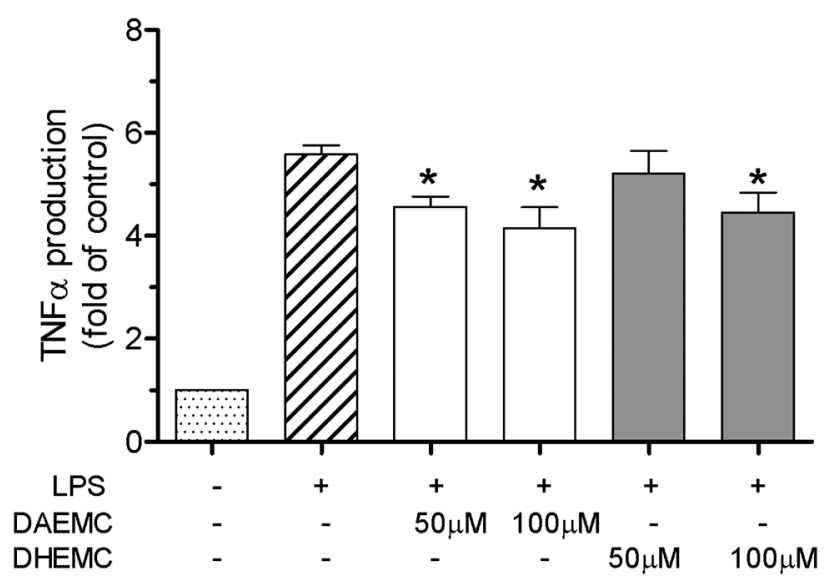

Fig. 4. Inhibitory Effect of 4-Methylcoumarin Derivatives on Rat Microglial Lipopolysaccharide (LPS)-Induced TNF- $\alpha$ Production

Primary rat microglial cultures were pre-incubated with DHEMC and DAEMC for $30 \mathrm{~min}$ and then stimulated with $10 \mathrm{ng} / \mathrm{mL}$ LPS. TNF- $\alpha$ concentrations were assayed in the medium by ELISA after $24 \mathrm{~h}$. The bars and error bars represent the mean and S.D., respectively. Significantly different from the value in LPS alone treated control cells: $* p<0.05(n=3)$.
Inhibition of TNF- $\alpha$ Production in Microglial Cells As showed in Fig. 4, TNF- $\alpha$ production induced by LPS in primary microglial cells was significantly reduced by both DHEMC and DAEMC at $100 \mu \mathrm{M}$. Only DAEMC showed an inhibitory effect at $50 \mu \mathrm{M}$.

Inhibition of Microglial Protein Expression of iNOS and COX-2 The effect of 4-methylcoumarin derivatives DHEMC and DAEMC $(100 \mu \mathrm{M})$ on LPS-induced iNOS and COX-2 expression in rat microglial cultures was examined by western blotting (Fig. 5). While both DHEMC and DAEMC were able to significantly inhibit COX-2 expression (Figs. 5A, B), only DAEMC significantly decreased LPS-induced iNOS protein expression (Figs. 5A, C).

Cyclooxygenase Inhibition COX-1 and COX-2 inhibitory activities of 4-methylcoumarin derivatives were measured in human whole blood assay. Although DAEMC induced a slight reduction in COX-1 activity, this effect was not significant and overall none of the compounds showed any significant effect on the activity of COX-1 and COX-2 enzymes (Fig. 6).

A

iNOS

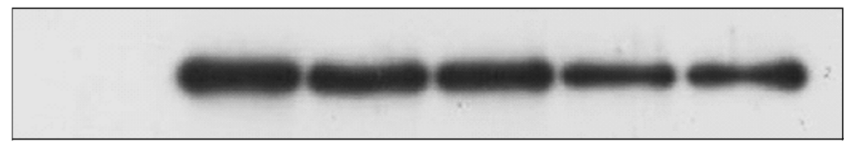

COX-2

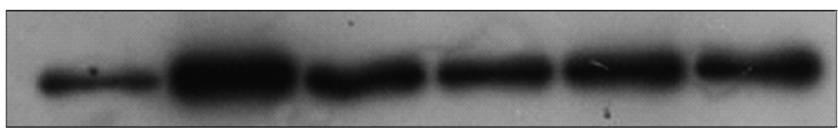

$\beta$-actin

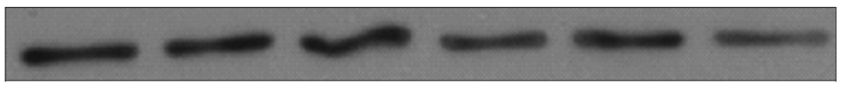

$\begin{array}{lcccccc}\text { LPS } & - & + & + & + & + & + \\ \text { DHEMC } & - & - & 100 \mu \mathrm{M} & 100 \mu \mathrm{M} & - & - \\ \text { DAEMC } & - & - & - & - & 100 \mu \mathrm{M} & 100 \mu \mathrm{M}\end{array}$

B

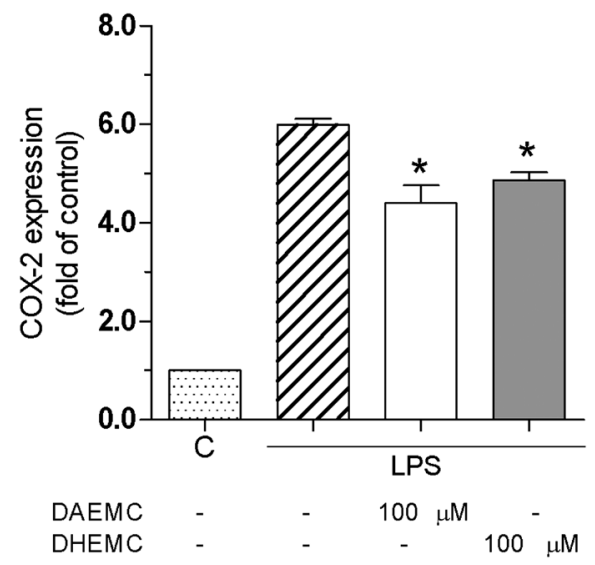

C

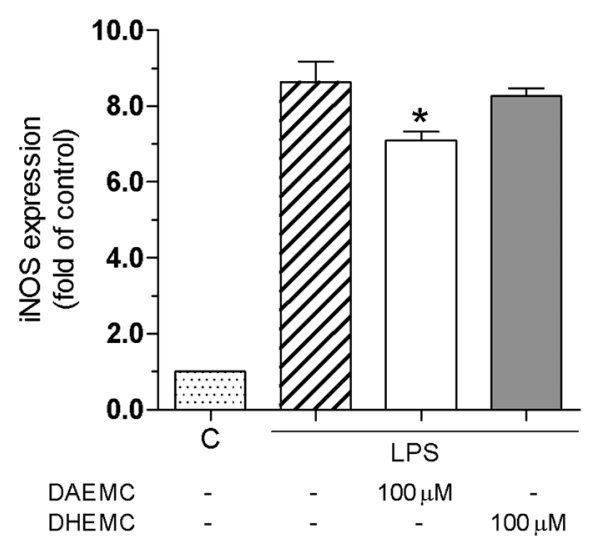

Fig. 5. Effect of 4-Methylcoumarin Compounds on Lipopolysaccharide (LPS)-Induced COX-2 and iNOS Expression in Rat Microglial Cells

Primary rat microglial cultures were pre-incubated with DHEMC and DAEMC for $30 \mathrm{~min}$ and then stimulated with $10 \mathrm{ng} / \mathrm{mL}$ LPS for $24 \mathrm{~h}$. COX-2 and iNOS expressions were determined by Western blot in harvested cells (panel A). The figure is representative of 4 different experiments. $\beta$-Actin was used as protein loading control. The densitometric data of COX-2 (B) and iNOS (C) protein expression were expressed as fold increase compared to C (basal level of COX-2 and iNOS expression without LPStreatment). Values are the mean \pm S.D. of 4 different experiments. Significantly different from cells treated with LPS alone: $* p<0.05$. 

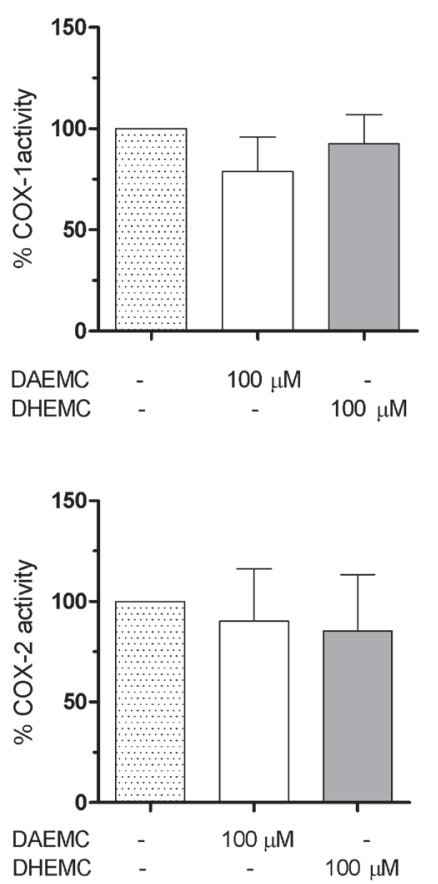

Fig. 6. COX-1 and COX-2 Inhibitory Activities of 4-Methylcoumarin Derivatives Determined with Whole Blood Assay

COX-1 and COX-2 inhibitory activities of DHEMC and DAEMC were measure with human whole blood assay by determining the levels of $\mathrm{TXB}_{2}$ and $\mathrm{PGE}_{2}$, respectively. Values are expressed as percent enzyme activity compared to control. None of the differences were statistically significant compared to control. Values are means of 4 different experiments.

\section{DISCUSSION}

In this study, the anti-inflammatory effects of two 4-methylcoumarin derivatives, DHEMC and DAEMC were tested in activated primary rat microglial cultures. These compounds were able to inhibit LPS-induced production of pro-inflammatory and neurotoxic mediators. These effects were accompanied with a decreased protein expression of inflammatory enzymes, iNOS and COX-2.

Inflammation in the CNS may contribute to the development of neurodegeneration. ${ }^{3,4,23)}$ Microglia, which are the main cellular components of the brain immune system, play an important role in the process of inflammation in the $\mathrm{CNS}^{3)}$ and their chronic activation may contribute to the development and progression of neurodegenerative diseases. ${ }^{24)}$ In this context, compounds that can modulate the neuroinflammatory processes may prove useful in the control of neurodegeneration. ${ }^{2,23)}$

Both 4-methylcoumarin compounds investigated in this study were able to exert anti-inflammatory effects in primary rat microglial cultures, evidenced by inhibition of proinflammatory and neurotoxic mediators $\mathrm{NO}, \mathrm{PGE}_{2}, \mathrm{TXB}_{2}$ and TNF- $\alpha$ production and also by lowering iNOS and COX-2 protein expression, but without any significant effect on COX-1 and COX-2 enzyme activities in whole blood assay.

None of the test compounds altered the base line prostanoids produced by microglial cells in the absence of LPS stimulation. Since base line prostanoids are mainly produced by the constitutive COX-1 enzyme, these compounds probably do not have a large effect on COX-1.

DAEMC appeared to be slightly more potent than DHEMC: DAEMC inhibited $\mathrm{NO}$ and prostanoid production starting from the dose of $50 \mu \mathrm{M}$, while DHEMC inhibited their produc- tion only at the dose of $100 \mu \mathrm{M}$. Furthermore, DAEMC was able to lower both iNOS and COX-2 expression at $100 \mu \mathrm{M}$, while DHEMC lowered the expression of COX-2, but not iNOS at the same concentration.

The reduced production of $\mathrm{NO}, \mathrm{TXB}_{2}$ and $\mathrm{PGE}_{2}$ can result either from the inhibition of the enzymatic activities and/or protein expression of iNOS and COX isoforms. In order to answer this important question, the COX enzyme inhibitory activity of these compounds were tested in the whole blood assay, which is considered a reliable method to measure the enzyme inhibitroy activities of various compounds. ${ }^{21,22)}$ These experiments demonstarted that DAEMC and DHEMC had no significant inhibitory effect on the COX-1 and COX-2 enzyme activities. Therefore, this provides more evidence for the assumption that the mechanism of action of these compounds is through the modulation of expression of inflammatory enzymes.

However, regarding iNOS, inhibitory effect of the methylcoumarin derivatives on the enzyme activity can not be excluded with the present data.

Previous studies have shown that various coumarin derivatives are able to inhibit LPS-induced $\mathrm{NO}^{10,25,26)}$ and $\mathrm{PGE}_{2}$ production $^{10)}$ in macrophages and other investigators have reported the ability of coumarin related compounds in lowering the protein expression of inflammatory enzymes. It has been observed that 7,8-diacetoxy-4-methylcoumarin reduces COX-2 expression in A549 human lung adenocarcinoma cells ${ }^{27)}$ and other authors, studying the effect of 63 natural oxycoumarin derivatives on LPS-induced inflammation in RAW264.7 cells, showed that many of these compounds inhibited the protein expressions of iNOS and COX-2. ${ }^{8)}$ Similarly, several naturally occurring coumarins including nodakenin, ${ }^{10)}$ glycyrol ${ }^{25)}$ and 3-(1'-1'-dimethyl-allyl)-6-hydroxy-7-methoxy-coumarin ${ }^{28)}$ reduce iNOS and COX-2 expression in LPS-stimulated macrophages. Another natural coumarin, osthole, which has immunomodulatory activities, also inhibits COX-2 expression in LPS-stimulated macrophages. ${ }^{26)}$ Our observation that 4-methylcoumarin derivatives reduce COX-2 and iNOS expression is in line with the above mentioned investigation that show the target of these compounds is at the protein expression level.

To our knowledge, iNOS seems to be the main subtype of NOS present in microglia. Yao and colleagues ${ }^{29)}$ have stated that there are 3 known isoforms of NOS; The constitutively active isoforms, neuronal NOS (nNOS) and endothelial NOS (eNOS), which are present in both neuronal and endothelial cells, in addition to the iNOS, which is expressed in response to cytokines and LPS in macrophages, monocytes and microglial cells. Therefore, this study was focused on the iNOS isoform.

According to some authors, the reduction in iNOS and COX-2 protein expression induced by coumarins is probably due to decreased mRNA transcription ${ }^{8,25)}$ caused by blocking of NF- $\kappa \mathrm{B}$ activation, which has been previously reported by other authors about coumarin compounds. ${ }^{23,26)}$

4-Methylcoumarin derivatives bearing 7,8-dihydroxy and 7,8-diacetoxy moieties have been reported to be potent antioxidant compounds. ${ }^{12-14)}$ Most of these reports have suggested that 7,8-dihydroxy confers higher activity compared to 7,8 -diacetoxy, ${ }^{13,14)}$ probably due the important contribution of catechol moiety to the antioxidant activity. However, in some papers this difference seems to be minimal. ${ }^{12)}$ 
Our findings showed that DAEMC bearing 7,8-diacetoxy moiety had a slightly better activity compared to 7,8-dihydroxy bearing compound, DHEMC. The difference in lipophilicity of DHEMC and DAEMC may also explain these differences. More lipophilic DAEMC is probably more efficient in crossing the lipid membranes in microglia and reaching its targets.

In conclusion, the two 4-methylcoumarin compounds investigated in this study showed considerable activities in modulation of inflammatory processes in rat microglial cells. Since neuroinflammation is an important part of the etiopathogenesis of neurodegenerative diseases, compounds that can effectively inhibit inflammatory processes are valuable sources for further development of agents designed for prevention or treatment of these diseases.

Acknowledgments The authors are grateful to Paola Patrignani for providing specific $\mathrm{PGE}_{2}$ antiserum. The financial support of Vice-Chancellor for Research, Shiraz University of Medical Sciences is also appreciated.

\section{REFERENCES}

1) Lambert JC, Heath S, Even G, Campion D, Sleegers K, Hiltunen M, Combarros O, Zelenika D, Bullido MJ, Tavernier B, Letenneur L, Bettens K, Berr C, Pasquier F, Fiévet N, Barberger-Gateau P, Engelborghs S, De Deyn P, Mateo I, Franck A, Helisalmi S, Porcellini E, Hanon O, de Pancorbo MM, Lendon C, Dufouil C, Jaillard C, Leveillard T, Alvarez V, Bosco P, Mancuso M, Panza F, Nacmias B, Bossù P, Piccardi P, Annoni G, Seripa D, Galimberti D, Hannequin D, Licastro F, Soininen H, Ritchie K, Blanché H, Dartigues JF, Tzourio C, Gut I, Van Broeckhoven C, Alpérovitch A, Lathrop M, Amouyel P; European Alzheimer's Disease Initiative Investigators. Genome-wide association study identifies variants at CLU and CR1 associated with Alzheimer's disease. Nat. Genet., 41, 1094-1099 (2009).

2) Etminan M, Gill S, Samii A. Effect of non-steroidal anti-inflammatory drugs on risk of Alzheimer's disease: systematic review and meta-analysis of observational studies. BMJ, 327, 128-131 (2003).

3) Khandelwal PJ, Herman AM, Moussa CE. Inflammation in the early stages of neurodegenerative pathology. J. Neuroimmunol., 238, 1-11 (2011).

4) Hoozemans JJ, Veerhuis R, Rozemuller JM, Eikelenboom P. Soothing the inflamed brain: effect of non-steroidal anti-inflammatory drugs on Alzheimer's disease pathology. CNS Neurol. Disord. Drug Targets, 10, 57-67 (2011).

5) Kostova I. Synthetic and natural coumarins as cytotoxic agents. Curr. Med. Chem., 5, 29-46 (2005).

6) Borges F, Roleira F, Milhazes N, Santana L, Uriarte E. Simple coumarins and analogues in medicinal chemistry: occurrence, synthesis and biological activity. Curr. Med. Chem., 12, 887-916 (2005).

7) Melagraki G, Afantitis A, Igglessi-Markopoulou O, Detsi A, Koufaki M, Kontogiorgis C, Hadjipavlou-Litina DJ. Synthesis and evaluation of the antioxidant and anti-inflammatory activity of novel coumarin-3-aminoamides and their alpha-lipoic acid adducts. Eur. J. Med. Chem., 44, 3020-3026 (2009).

8) Nakamura T, Kodama N, Oda M, Tsuchiya S, Arai Y, Kumamoto T, Ishikawa T, Ueno K, Yano S. The structure-activity relationship between oxycoumarin derivatives showing inhibitory effects on iNOS in mouse macrophage RAW264.7 cells. J. Nat. Med., 63, 15-20 (2009).

9) Sandhya B, Giles D, Mathew V, Basavarajaswamy G, Abraham R. Synthesis, pharmacological evaluation and docking studies of coumarin derivatives. Eur. J. Med. Chem., 46, 4696-4701 (2011).
10) Rim HK, Cho W, Sung SH, Lee KT. Nodakenin suppresses lipopolysaccharide-induced inflammatory responses in macrophage cells by inhibiting TRAF6 and NF-kappaB pathways and protects mice from lethal endotoxin shock. J. Pharmacol. Exp. Ther., 342, 654-664 (2012).

11) Kumar S, Singh BK, Kalra N, Kumar V, Kumar A, Prasad AK, Raj HG, Parmar VS, Ghosh B. Novel thiocoumarins as inhibitors of TNF-alpha induced ICAM-1 expression on human umbilical vein endothelial cells (HUVECs) and microsomal lipid peroxidation. Bioorg. Med. Chem., 13, 1605-1613 (2005).

12) Pedersen JZ, Oliveira C, Incerpi S, Kumar V, Fiore AM, De Vito P, Prasad AK, Malhotra SV, Parmar VS, Saso L. Antioxidant activity of 4-methylcoumarins. J. Pharm. Pharmacol., 59, 1721-1728 (2007).

13) Mladenka P, Macakova K, Zatloukalova L, Rehakova Z, Singh BK, Prasad AK, Parmar VS, Jahodar L, Hrdina R, Saso L. In vitro interactions of coumarins with iron. Biochimie, 92, 1108-1114 (2010).

14) Morabito G, Trombetta D, Singh BK, Prasad AK, Parmar VS, Naccari C, Mancari F, Saija A, Cristani M, Firuzi O, Saso L. Antioxidant properties of 4-methylcoumarins in in vitro cell-free systems. Biochimie, 92, 1101-1107 (2010).

15) Ronad P, Dharbamalla S, Hunshal R, Maddi V. Synthesis of novel substituted 7-(benzylideneamino)-4-methyl-2H-chromen-2-one derivatives as anti-inflammatory and analgesic agents. Arch. Pharm., 341, 696-700 (2008).

16) Kancheva VD, Saso L, Angelova SE, Foti MC, Slavova-Kasakova A, Daquino C, Enchev V, Firuzi O, Nechev J. Antiradical and antioxidant activities of new bio-antioxidants. Biochimie, 94, 403-415 (2012).

17) Kancheva VD, Saso L, Boranova PV, Khan A, Saroj MK, Pandey MK, Malhotra S, Nechev JZ, Sharma SK, Prasad AK, Georgieva MB, Joseph C, DePass AL, Rastogi RC, Parmar VS. Structureactivity relationship of dihydroxy-4-methylcoumarins as powerful antioxidants: correlation between experimental \& theoretical data and synergistic effect. Biochimie, 92, 1089-1100 (2010).

18) Parmar V, Singh S, Boll P. ${ }^{13} \mathrm{C}$ Nuclear magnetic resonance spectroscopy of 4-methylcoumarins (4-methyl-2H-1-benzopyran-2-ones). Magn. Reson. Chem., 26, 430-433 (1988).

19) Giulian D, Baker TJ. Characterization of ameboid microglia isolated from developing mammalian brain. J. Neurosci., 6, 2163-2178 (1986).

20) Patrignani P, Panara MR, Greco A, Fusco O, Natoli C, Iacobelli $S$, Cipollone F, Ganci A, Créminon C, Maclouf J, Patrono C. Biochemical and pharmacological characterization of the cyclooxygenase activity of human blood prostaglandin endoperoxide synthases. $J$. Pharmacol. Exp. Ther., 3, 1705-1712 (1994).

21) Gierse JK, Zhang Y, Hood WF, Walker MC, Trigg JS, Maziasz TJ, Koboldt CM, Muhammad JL, Zweifel BS, Masferrer JL, Isakson PC, Seibert K. Valdecoxib: assessment of cyclooxygenase-2 potency and selectivity. J. Pharmacol. Exp. Ther., 312, 1206-1212 (2005).

22) Moradi A, Navidpour L, Amini M, Sadeghian H, Shadnia H, Firouzi O, Miri R, Ebrahimi SE, Abdollahi M, Zahmatkesh MH, Shafiee A. Design and synthesis of 2-phenoxynicotinic acid hydrazides as anti-inflammatory and analgesic agents. Arch. Pharm, 343, 509-518 (2010).

23) Doherty GH. Nitric oxide in neurodegeneration: potential benefits of non-steroidal anti-inflammatories. Neurosci. Bull., 6, 366-382 (2011).

24) Smith JA, Das A, Ray SK, Banik NL. Role of pro-inflammatory cytokines released from microglia in neurodegenerative diseases. Brain Res. Bull., 87, 10-20 (2012).

25) Shin EM, Zhou HY, Guo LY, Kim JA, Lee SH, Merfort I, Kang SS, Kim HS, Kim S, Kim YS. Anti-inflammatory effects of glycyrol isolated from Glycyrrhiza uralensis in LPS-stimulated RAW264.7 macrophages. Int. Immunopharmacol., 8, 1524-1532 (2008).

26) Liao PC, Chien SC, Ho CL, Wang EI, Lee SC, Kuo YH, Jeyashoke N, Chen J, Dong WC, Chao LK, Hua KF. Osthole regulates 
inflammatory mediator expression through modulating NF-kappaB, mitogen-activated protein kinases, protein kinase $\mathrm{C}$, and reactive oxygen species. J. Agric. Food Chem., 58, 10445-10451 (2010).

27) Goel A, Prasad AK, Parmar VS, Ghosh B, Saini N. Apoptogenic effect of 7,8-diacetoxy-4-methylcoumarin and 7,8-diacetoxy-4methylthiocoumarin in human lung adenocarcinoma cell line: role of NF-kappaB, Akt, ROS and MAP kinase pathway. Chem. Biol. Interact., 179, 363-374 (2009).
28) Raghav SK, Gupta B, Shrivastava A, Das HR. Inhibition of lipopolysaccharide-inducible nitric oxide synthase and IL-1beta through suppression of NF-kappaB activation by 3-(1'-1'-dimethyl-allyl)6-hydroxy-7-methoxy-coumarin isolated from Ruta graveolens L. Eur. J. Pharmacol., 560, 69-80 (2007).

29) Yao SY, Natarajan C, Sriram S. nNOS mediated mitochondrial injury in LPS stimulated oligodendrocytes. Mitochondrion, 12, 336-344 (2012). 